\title{
Role of Ayurved in Sport Medicine: A Short Review
}

\author{
*Dnyaneshwar Kantaram Jadhav \\ Shree Dhanwantari Ayurved medical college, India
}

Submission: March 11, 2017; Published: March 17, 2017

*Corresponding author: Dnyaneshwar Kantaram Jadhav, Shree Dhanwantari Ayurved medical college, Mathura, India, Tel: 08451834859; 9664045849; Email: dj85015@gmail.com

\begin{abstract}
Ayurveda is the ancient Indian system of medicine. The term Ayurveda combines two Sanskrit words AYU which means life and Veda which means knowledge or science. It is one of the oldest systems of medicine in the World still that truth to the time. Sports medicine is a branch of medicine that deals with physical fitness and the treatment and prevention of injury related to sport and exercise. Direct references of this neither mentioned in ancient nor in modern medicine. It is nothing but the application of various medical principles to the sports activities, physical exercise and performance. When we go through the Ayurvedic samhita we definitely do not find direct references regarding a specialty called sports medicine nor do we have readymade management for sports related things. After lot of close observation and correct interpretations of Ayurvedic texts, we will get idea about how to deals with sports medicine. The Aims of this review article is to exploring hidden references and scope of Ayurveda in sport medicine.
\end{abstract}

Keywords: Ayurveda; Sports medicine

\section{Introduction}

\section{Relevence of Ayurveda}

Ayurveda is art and science of life. The term Ayurveda combines two Sanskrit words AYU which means life and Veda which means knowledge or science [1]. Ayurveda related about prevention and curative both aspects [2]. Although there had been many innovations and additions to the practice of Ayurveda subsequently, but principles of Ayurveda remain the same. That is the beauty of this life science.

\section{Sports Medicine}

Sports medicine is a branch of medicine that deals with physical fitness and the treatment and prevention of injury related to sport and exercise [3]. Concussion, muscle cramp, ACL (the anterior cruciate ligament) sprains/tear, ankle sprain, shin splints, muscle strains or fracture is common sport injury [4]. Sports medicine has always been difficult to define because it is not a single specialty, but an area that involves many branches. Its function is not only curative and rehabilitative, but also preventative, which may actually be the most important one of all [5]. Sports medicine can encompass an array of specialties, which including cardiology, pulmonology, orthopedic surgery, psychiatry, exercise physiology, biomechanics, and traumatology [6]. In sport medicine, as per the type of event and the activity, treatment modality will also vary.

\section{Ayurveda and sports medicine}

Sports medicine, as a separate medical specialty in medicine filed. Ayurved act as preventive and curative both side, so it is best science which play major role in sport medicine. As we go through the Ayurvedic literature, there is no direct references regarding sports medicine. Even there is no ready-made management plans regarding sports related things. As we does not getting direct reference than most of people concluding that "Ayurveda has nothing to do with sports medicine". But when we observe with the open mind with curious scientist, we find enormous things. From dincharya to achar Rasayana each and every things is play important role in sport science. If we carry a systematic research than Ayurveda could revolutionize \& contribute a great. There are seven dhatu [7] (body-tissues) that give form and shape to the human body. In sport medicine mansa (Muscles), asthi (bones) is main dhatu \& snayu (ligaments), kandra (tendons) are upadhatu which deals with sport injury. According to Ayurvedic system of medicine, Functions of asthi (Bones) is giving shape and structure to our body [8]. Ligaments, muscles and tendons are connected to asthi. Having strong bones means having a strong body.

I. Symptoms of Asthivriddhi include [9]

i. Adhyasthi (bony-hypertrophy)

ii. Adhidanta (extra teeth formation)

II. Symptoms of Asthikshaya include [10]

i. Asthibhagna (pathological fractures) 

ii. Asthikshaya (osteoporosis)
iii. Asthitoda (Inflammation of bones and joints)
iv. Asthivrana (osteomyelitis)
v. Dwijaprapatana (falling of teeth)
vi. Phakkaroga (rickets)
vii. Sadana (weakness)
viii. Srama (fatigue)

III. Sports injury as per Ayurveda Concepts as
i. Bhagna [11] (fractures \& dislocations)
ii. Sadyovrana [12] (acute wounds).
iii. Snayugata Vaata [13] (Tendon \& Ligament injury)
iv. Vrana [14] (wounds)
v. Vranashotha (inflammatory conditions)

\section{Sports Injury Related Conditions in Ayurveda}

i. Bhagna: Bony injuries

ii. Kandaragatvata : Tendon injury Ligament versus tendon
iii. Mamsagatvata: Sprain, \& Fatigue syndrome
iv. Sandhimukta: Jointinjuries (dislocation, \& subluxation).
v. Snayugatvata: Ligament, Nerve \& Bursa injuries

\section{Treatment protocols in Ayurvedic sports medicine}

i. Management of injuries

ii. Rehabilitation of injuries

iii. Active mobilization

iv. Passive mobilization

v. Strengthening

\section{Internal medication}

The chief aim of Internal Medication is

i. To boost up tissue healing

ii. To alleviate pain

iii. In order to strengthen the injured part

\section{External therapies}

The chief aim of External Therapies is

i. To alleviate pain

ii. Strengthens joints

iii. To improve function

\section{Lepana / Aalepa / Upanaha}

The chief aim of Lepana / Aalepa / Upanahais [15]

i. To alleviate pain

ii. To promote tissue healing

IX. Kati vasti: It is very effective in low back pain, muscular pain and fatigue syndrome.

X. Bandhana: Bandage with or without oil massage. 15 types of Vrana Bandhana are described in Ayurveda [16] .

XI. Anushastra Karma: These include Para Surgical Procedures including Agnikarma (direct heat application) and Raktamokshana: (Blood Letting Therapy). Both reduce inflammation, alleviate pain and promote healing.

\section{Discussion}

References in Ayurvedic texts which can be correlated with sports medicine discussed here -

\section{Role of Dashvidha-pariksha in sports medicine}

As modern science conduct many exams for fitness like weight, chest, running etc. Same, in Ayurveda there are 10 examinations are mentioned, which is known as dashavidhapariksha [17]. It will be useful for selection of the athlete.

A. Prakruthi (constitution of the body): The physical fitness and performance are important in sport area. It's influenced by the constitution of the human body. There are total 7 Prakruthi according to Vata, Pitta and Kapha and their combinations. They will remain unchanged till the death of the individual. Prakruthi is formed at the time of fertilization [18]. From observation it is conclude that vata prakruthi person can be a better athlete than a kaphaprakruthi person. Similarly a person specializing in chess should be kapha predominant person.

B. Vikruthi: its guess on the bases of dosh-dushya, prakruti, desh, bala, kala. Modernpathy can be similar to vikruthipariksha, in which first they do study of disease then study of patients and afterward disease management.

C. Sara: There are seven dhatus in our body. The term Sara means highest purity of specific dhatus. Tvaksara, Raktasara, Mamsasara, Medosara, Asthisara, Majjasara, Sukrasara, Satwasara, Ojosara (Kasyapa). Out of these the Asthisara and Majjasara individuals can be a best sports person.

i. Charactersitics of Asthisara [19] are: Bones are strong, prominent joints at gulfa (heels), janu (ankles), Aratni (elbows), jatru (shoulders), thick Nakha (nails), sthuladanta (prominent teeth). They possess high energy and are addicted to actions. They are capable of bearing pain and fatigue. Their body will be slim but strong and firm. They are best suitable for hard physical activities, sports and war. 
ii. Charactersitics of Majjasara [20] are: It is related to Majjadhatu. Majjasara are with small body and having good endurance, strong bones and joints. They are oily in complexion and are very agile. They are endowed with good physical stamina, power, knowledge, and demand dignity and respect.

D. Samhananam (Compactness): A compact body is characterized by symmetrical and well grown bone, well-knit joints and well bound muscles. Its decide power of person. Compactness has significance in events such as weight lifting sprinting etc.

E. Pramana: The word pramana means measurement. By the measurement of the body organs the, quality and strength of a person can be ascertained. It's give idea of life of person. To be an outstanding athlete one should possess unique proportion of the body other than the normal individual which enable them high mechanical advantage thereby an edge above the fellow competitor.

F. Satmya: Satmya is defined as inbuiltability to withstand. This goes hand in hand with constituents (Prakruthi). There are 4 types of satmya out of which Oka satmya or Vyayamasatmya of Charaka and Susrutha respectively can be dealt in detail here. Oka satmya means the adaptability of a person to a particular activity. It depends upon the daily activity and repetition of an activity increases the ability of the body to continue the same.

G. Satwam: Satwam is mind. To be a good athlete one should not only have a strong body but a capable mind. Depending upon the strength the mind is of three types Pravaram (Superior), Madhyamam (Mediocre) Avaram (Inferior)

H. Aaharsakthi: It depend on abahvaranashakti (quantity of food which can be eaten) \& jaranshkati (quantity of food which can be digested). In sport filed person need stamina so it's important examination related to diet.

I. Vyayamasakthi: It is the capacity to perform physical exercise. Nowadays sports person are not just musculo-skeletal but it also include physical, physiological psychological social, economic, environmental stresses. An Ayurveda approach is holistic, where in it combines modalities with Yoga \& Pranayama. It can effectively work towards stress relieving and in developing concentration.

J. Vaya: It is also important factor related to sport medicine. Young person is best for sport because he have best energy level. As age increased body start to degenerate hence power of person getting decreased.

\section{Role of snehan and swedan in sports medicine}

Snehan act as lubrication for whole body, ultimately to all joints. It makes body flexible. With swedan all toxic material, oxidants in the body removed out from body. Its combine act as painkiller action also.

\section{Role of natural performance enhancing agents}

In any heavy work, person needs instant energy. In ancient times also warriors use some herbal drugs to enhance their performance during war and from which they not getting tired easily. Maharshicharak describe the 50 Mahakashayain charaka Samhita [21]. Brimhaneeyadasaimani (Muscle builder), Jeevaneeya Dasaimani (Vitiliser), BalakaraDasaimani (Promotes strength) and Sramaharadasaimani (Promotes cheer) drugs are said to have components that can enhance the performance level. These drugs are non-steroidal and probably act by increasing the secretion of the biological hormones and enzymes. Draksha, Priyala, Barbara, Dadima, Parooshaka, Iksu, Yava, Shastika, Phalgu, Jeevaka, Rishabhaka, meda, Mahameda, Kakoli, Ksheerakakoli, Mudgaparna, Mashaparni, Jeevanti are examples of such Natural performance enhancing agents.

\section{Marma and sports medicine}

Marmas are vital points in the body. There are 107 vital points in body which called as marma. An injury to any of these marmas may cause severe pain, swelling, disability and even death. Many of the marma points have great importance in the treatment of sports injuries, like acupressure points in Chinese medicine. Injuries, trauma are common in the sports [22]. This can be physically or mentally. Trauma or injury on this point can be brings disability or death.

\section{Role of panchakarma in sports medicine :}

Panchakarma is getting popularity due to its instant magical result \& prevent recurrence of disease. Sport medicine also concentrated on curative and rehabilitative \& also preventive like Ayurved. Our body takes its own time from recovery of any disease. In sport filed person need daily exercise and follow his schedule to achieve his target. Ayurved can give best schedule via Dinchrya and Rutuchrya and panchkram can keep them healthy. Even in trauma like condition Raktamoskna is best panchakrma which give instant relief from pain and prevent occlusion of blood in that specific area [23].

\section{Role of rasayana therapy in sports medicine}

Rasayana or rejuvenation therapy is one of the eight major clinical disciplines of Ayurveda, which plays a pivoted role in dealing the process of ageing [24]. By Rasayana therapy an individual will get longevity of lifespan, memory power, intelligence, heath, youth, lustre, and complexion, and good voice, stronger sensory and motor organ. Vacha, Raupyabahsama are RasyanadrvayaS which act on Majjavahastrotas. While abha like Rasayanadravaya useful in Asthivahastrotus.

\section{Conclusion}

Ayurveda is science of life which test to the time. Even sport medicine is new branch developed, still Ayurved has all solution related to sport science. Ayurvedic medicines have potent action in acute \& chronic injuries. Use of external application and 
internal medication found to be best in the healing of injuries and prevent edema, stiffness, muscle wasting compared to modern treatment. Early mobilization and proprioception is the great advantage of Ayurvedic combination therapy compared to modern treatment play key role in Rehabilitation in sports. Ayurveda can creates miracles in various kinds injuries like tennis elbow, heel pain (plantar Fasciitis, heal spur, highland's syndrome, Achilles tendinitis, tenosynovitis, groin injury, long Lasting patellar tendinitis, supra spinatus tendinitis with shorter duration of time compared to modern medicine. Many surgical conditions like meniscal tear, rotator cuff tear, ligament tear, condylar fracture. Patellar dislocation, recurrent shoulder dislocation, back pain and neck pain due to inter vertebral disc disease can be treated and recovered in shorter span of time by integrated method. Degenerative diseases like osteoarthritis, per arthritis affecting the old age can be successful brought back to normal stage and patient can move without pain safely in low treatment cost. Performance enhancement and attaining physical and mental fitness all this can achieve with Ayurveda in sports medicine.

\section{References}

1. YG Joshi (2011) Charaksamhita, Maharshi Charak, Marathi commentary elaborated by caraka \& Drudhabala. Sutra - Stan $\left(1^{\text {st }}\right.$ edn), chapter 1 , Verse no.43, vaidyamitraprakashan, India, p.16.

2. Anant Ram Sharma edited with 'susrutavimarsini' Hindi commentary (2010) Susrutasamhita, maharshisusruta. Sutra-stan ( $1^{\text {st }}$ edn), Chapter 1, verse no.13, Chukhambhaprakashan, India, p.8.

3. https://en.m.wikipedia.org/wiki/sports_medicine.

4. JN Wilson (1982) Watson and Jones' textbook on Fractures and joint injuries, edited by J.N.Wilson. $\left(6^{\text {th }}\right.$ edn), Volume $1,9^{\text {th }}$ chapter, Jama publication, India, pp.986.

5. Ronald Mc Rae (1983) Clinical orthopaedic Examination. (2 $2^{\text {nd }}$ edn) chapter no.5, ELBS publication, India, pp.487.

6. Kapoor OP Kapoors (2000) Text book of medicine for general practitioners. Volume 1, SS publishers, India, pp.240.

7. Subhashranade (2006) Ashtangasangraha, Vagbhtakrytaindutika and its Marathi translation. Sutra stan, $\left(12^{\text {th }}\right.$ edn $)$, chapter 1 , Verse no.29, Anmol publishing house, India, p.5.

8. Subhashranade (2006) Ashtangasangraha, Vagbhtakrytaindutika and its Marathi translation. Sutra stan $\left(12^{\text {th }}\right.$ edn $)$, chapter 1 , Verse no.31, Anmol publishing house, India, p.5.

9. Ganesh Krushanagarde (2009) Sartha Vagbhat, Vagbhtakryta Ashtangrudhaya and its Marathi translation. Sutra stan $\left(12^{\text {th }}\right.$ edn), chapter 11, Verse no.10, Profesent publishing house, India, p.59.
10. Ganesh Krushanagarde (2009) Sartha Vagbhat, VagbhtakrytaAshtangrudhaya and its Marathi translation. Sutra stan $\left(12^{\text {th }}\right.$ edn), chapter 11 , Verse no.18, Profesent publishing house, India, p.60.

11. Anant Ram Sharma edited with 'susrutavimarsini' Hindi commentary (2010) Susrutasamhita, maharshisusruta. Chikitsa-stan, Chapter 3, verse no.1, Chukhambhaprakashan, India, pp.189.

12. Anant Ram Sharma edited with 'susrutavimarsini' Hindi commentary (2010) Susrutasamhita, maharshisusruta. Chikitsa-stan, Chapter 2, verse no.1, Chukhambhaprakashan, India, pp.175.

13. Anant Ram Sharma edited with 'susrutavimarsini' Hindi commentary (2010) Susrutasamhita, maharshisusruta. Chikitsa-stan, Chapter 4, verse no.8, Chukhambhaprakashan, India, pp.205.

14. Anant Ram Sharma edited with 'susrutavimarsini' Hindi commentary (2010) Susrutasamhita, maharshisusruta. Chikitsastan, Chapter 1, verse no.3, Chukhambhaprakashan, India, pp.151.

15. Brhamananda Tripathi (2010) Sharangadharsamhita, Maharshi Charak, hindi commentary, dioikatika, maharshiagniveshrut, utarkdhanda. $\left(1^{\text {st }}\right.$ edn), chapter 11 , Verse no.1, Chukhambhasurbharti prakashan, India, pp.391.

16. Anant Ram Sharma edited with 'susrutavimarsini' Hindi commentary (2010) Susrutasamhita, maharshisusruta. Chikitsa-Stan, Chapter 3 Verse no.6, Chukhambhaprakashan, India, pp.189.

17. YG Joshi (2011) Charaksamhita, Maharshi Charak, Marathi commentary elaborated by charaka \& Drudhabala. Viman Stan ( $1^{\text {st }}$ edn $)$, chapter 8 , Verse no.94, Vaidyamitraprakashan, India, pp.597.

18. Anant Ram Sharma edited with 'susrutavimarsini' Hindi commentary (2010) Susrutasamhita, maharshisusruta. Sharir-stan, Chapter 4, Verse no.62, Chukhambhaprakashan, India, pp.453.

19. YG Joshi (2011) Charaksamhita, Maharshi Charak, Marathi commentary elaborated by charaka \& Drudhabala. Viman Stan ( $1^{\text {st }}$ edn), chapter 8 , Verse no.107, Vaidyamitraprakashan, India, pp.601.

20. YG Joshi (2011) Charaksamhita, Maharshi Charak, Marathi commentary elaborated by charaka \& Drudhabala. Viman Stan ( $1^{\text {st }}$ edn), chapter 8 , Verse no.108, Vaidyamitraprakashan, India, pp.601.

21. YG Joshi (2011) Charaksamhita, Maharshi Charak, Marathi commentary elaborated by charaka \& Drudhabala. Sutra-Stan ( $1^{\text {st }}$ edn), chapter 4 Verse no.19, Vaidyamitraprakashan, India, p.75.

22. Natarajan (1992) Text Book of orthopaedics and traumatology Section II. ( $3^{\text {rd }}$ edn), pp.1127.

23. Brhamananda Tripathi (2010) Sharangadharsamhita, Maharshi Charak, hindi commentary, dioikatika, maharshiagniveshrut, uttarkdhanda. Kushtaadhya ( $1^{\text {st }}$ edn), chapter 12 , Verse no.2, Chukhambhasurbharti prakashan, India, pp.415.

24. Gayatri Deshpande (2013) Mauliksiddantevam Ashtangarhudaya. Sutra-Stan, chapter 1, verse no.5, Shri Ram prakashan, India, p.2. 


\section{Your next submission with Juniper Publishers will reach you the below assets}

- Quality Editorial service

- Swift Peer Review

- Reprints availability

- E-prints Service

- Manuscript Podcast for convenient understanding

- Global attainment for your research

- Manuscript accessibility in different formats

( Pdf, E-pub, Full Text, Audio)

- Unceasing customer service

Track the below URL for one-step submission https://juniperpublishers.com/online-submission.php 